\title{
INTRODUCTION
}

\section{1 \\ Changing calculus and shifting visions}

\section{Stewart Firth and Jon Fraenkel}

The mood in Fiji following the 2006 election was positive. Not only had the two major parties performed strongly and confirmed themselves as the unequivocal representatives of their respective communities, but Fijian and Indian ministers were working together at last. If those who drew up the 1997 constitution were right, such cooperation could be expected to bring stability and harmony to the country. Unexpectedly, the constitutional provisions for power-sharing were implemented with the entry into government of a group of ministers from the largest losing party. Given the worsening state of the country's foreign reserves and the decline of the sugar and garment industries, the election outcome and its aftermath seemed to be another of those good strokes of fortune that the people of Fiji have come to expect. The 1987 coup, after all, could have ended in brutal dictatorship, but it did not. The 2000 coup could have split the army down the middle, but instead it isolated a small group of military rebels, leaving the commander in control and making possible a return to constitutional government. Twice on the edge of disaster, Fiji twice avoided it.

Fiji had seemed doomed to increasingly frequent instability when George Speight and his followers seized control of parliament in May 2000. Each of Fiji's three constitutions had lasted a shorter time - the 1970 constitution for 17 years, the 1990 constitution for eight years and the 1997 constitution (which came into effect in 1998) for fewer than two years until it was abrogated by the Republic of Fiji Military Forces in the wake of Speight's so-called civilian 
coup. But a series of court judgements set Fiji back on the path to constitutional democracy. In the Chandrika Prasad case of March 2001, Fiji's Court of Appeal declared that the 1997 constitution remained the supreme law of the land and had not been abrogated. A High Court ruling later approved the president's dissolution of parliament, opening the way for elections in August 2001, when the prime minister, Laisenia Qarase, led his newly formed Soqosoqo Duavata ni Lewenivanua (SDL) party to its first victory. Remarkably, the judicial system retained its integrity and continued to command the respect of political leaders. On the heels of his arrest by the military, George Speight was convicted of high treason and sentenced to death, although this was commuted to life imprisonment by the Prerogative of Mercy Commission. Ironically, the forces responsible for saving Fiji democracy - the military and the law courts - were both un-elected institutions.

But where did that leave democracy in Fiji? The 2001 election established majority rule - of a sort. The SDL won, although the Fiji Labour Party (FLP) gained the larger share of first preference votes. Majority rule had never sat easily on Fiji's communal soil. Three times, mainly Indian-backed parties had won elections; the first time the consequence was a constitutional crisis and, after that, the result was in both cases a coup. The outcome was always the same - a reversion to Fijian-controlled government. Indian leaders seemed perpetually relegated to sit on the opposition benches. The 2001 election put the politicians back in charge, opening yet another era of fraught top-level intercommunal rivalry. Not for the first - or the last - time there was a successful bid for indigenous Fijian unity in the face of the 'Indian threat', echoing the experiences at elections in the 1970s and 1980s.

So too at the 2006 election. Democracy seemed to work, but not many people wanted to ask whether or not democracy had in fact been put to the test. Would the mood have been so positive if the FLP had won, and Labour leader Mahendra Chaudhry become prime minister for a second time, even supposing he had invited members of the defeated Fijian party into his cabinet? Had that happened, Labour would have risen to power without anything resembling the coalition with Fijian allied parties that it had built at the time of its previous victory in 1999. If so, would people have expected stability, or would they have feared another 2000, when Chaudhry's Labour government was overthrown in 
the name of the rights of indigenous Fijians? In other words, does democracy work in Fiji only so long as the indigenous Fijians win the elections?

The answer to that question has historically been yes, although whether that was inevitably so is more difficult to judge. The historical reason for the affirmative answer lies in Fiji's colonial past as well as in its political experience since independence. The British transformed Fiji politically, economically and demographically, but they did not obliterate all that was distinctively Fijian. They created a modern state with a modern bureaucracy, the most effective in the South Pacific, but they also enshrined within it an indigenous Fijian state-within-the-state that resonated with the echoes of an older order. They created a modern economy, underpinned by the sugar industry; and they brought so many plantation labourers from India that, by the time the Union Jack was lowered for the last time in 1970, the descendants of those labourers were in the majority. In the Fijian villages, life was much changed compared with the pre-cession years, but ancient affiliations and practices survived in a manner interlaced with superimposed British versions of Fijian tradition: the provincial council, the Roko Tui and the Buli. ${ }^{1}$ As the certainties of the old order began to crumble, the church also played an increasingly powerful cohesive role for Fijians.

Protecting Fijians had been the leitmotif of British colonial rule. The number of Fijians fell continuously for the first 45 years after cession in 1874, and the early colonists feared the indigenous peoples would disappear completely unless cushioned from the harsh impact of market forces. Protecting Fijians meant keeping them in their villages under the authority of traditional chiefs until well after World War II. British rule had not always been so benign, only periodically so. In the first 20 or so years of the 20th century, an alliance between the colonists and the Indians seemed distinctly possible, and likely to lead to ever-increasing encroachments onto Fijian lands. ${ }^{2}$ But when, under pressure from colonial India, continued bonded labour migration from the subcontinent became clearly impossible, the calculus changed. When the nolonger indentured Indian labourers went on strike in Suva, and when their leaders began to demand greater political rights, the temporary rift between the colonists and the Fijians was gradually mended. World War II cemented that marriage, at least for Fiji's towering 20th century chief, Ratu Sir Lala Sukuna. 
For Fijian commoners, life in the colony was less hospitable. But Fijian soldiers fought hard for the British cause during the Pacific War. For their services, Ratu Sukuna was entrusted with reinventing the Fijian administration, or a bowdlerized version of it. The tikinas were amalgamated and villagers were pressed into new towns. The late 1940s and 1950s was an era of restraint for the indigenous community, and frustrations grew. By the 1960s, educated Fijians were earnestly demanding change, and the dismantling of Ratu Sukuna's Fijian order hastened indigenous movement into the towns and into the formal sectors of the economy.

For the Indian community, the 1920s and 1930s had been years of advancement. The era of indenture had ended, and advancement in the schools and a flowering of religion proceeded apace, along with a continuing movement of Indians towards the towns. Defeat of political demands, as for minority communities elsewhere in the world, served to invigorate social and economic advancement. Yet, by the mid-1940s, the Indians were no longer a minority. And with the coming twilight of the colonial order, as debates began to rage about suitable post-colonial institutions in the mid 1960s, the calculus of demography played a central role. With a common roll, the Indians might take control of government. With a communal roll, embellished with the old rhetoric of Fijian protectionism, the indigenous community might feel safe. The British colonists were not wholly insensitive to these sensibilities, but they had no workable answer. Land leasing by Indian farmers from Fijian landowners, for example, was made subject to statutory renewals, generating a periodically inevitable conflict in the legislature that echoed down to the 2006 election. ${ }^{3}$ At the London conference of 1965, a highly elaborate 'cross-voting' system was introduced, in the hope of elevating politicians of national standing, able to draw on support from both the major communities. ${ }^{4}$ It did not work. And, as with land leasing, the debates about Fijis electoral system proved to be perpetual sources of contention.

By the 1960s, the stage was set for Fijian politicians to adopt a highly defensive posture in their approach to national politics. A minority in their own country, and only recently acquainted with the concepts of elections and voting, the Fijians were determined to ensure that democracy, if that were unavoidable, should work in favour of the indigenous community. More than that, it should 
work in favour of the high chiefs, who had, since 1904, nominated Fijian representatives to the Legislative Council. They lost that monopoly in 1963, when commoners for the first time were allowed to vote. But in the finally agreed constitutional arrangements left behind by the British in 1970, the Council of Chiefs remained recognized and powerful by being able to appoint eight of the 22 members of the Senate and veto any legislation affecting Fijian interests. In sympathy with Fijian sensitivities, communal representation remained the bedrock of the post-colonial constitutional arrangements, lest the Indians take control by virtue of superior numbers. ${ }^{5}$ Fijis three post-independence constitutions all left a substantial space for communal representation, gently moulding the conduct of elections into a basically race-based experience for which, as Paul Geraghty notes in this volume, one wears one's Sunday best. Fijian chiefs did not easily settle back into a ceremonial role, a mere decoration on the new order, but dominated post-colonial national politics through the governing Alliance Party, under the leadership of Tui Nayau, Ratu Sir Kamisese Mara.

The vision of a multiracial Fiji espoused by Ratu Mara rested on the Alliance Party bringing together its Fijian, General Voter and Indian associations in a multi-ethnic government rather than a multiparty government. The first postindependence election, held in the context of a search for unanimity in the new and difficult post-colonial circumstances, gave that party its strongest ever showing. None of the later Fijian mainstream parties was ever able to repeat the Alliance's 1972 achievement of obtaining 25 per cent of the Indian vote. Yet Ratu Mara, like Laisenia Qarase in 2006, was constantly disappointed that Indians would never vote in sufficient numbers for his party. He felt betrayed. The Alliance never picked up a single Indian communal seat, and its great rival, the Federation Party, never picked up a single Fijian communal seat.

Still worse, Ratu Mara's shift to the political centre in search of Indian votes gave birth to a threat on his other flank. In the mid-1970s, the Fijian Nationalist Party emerged, demanding a 'Fiji for the Fijians' and condemning Britain for saddling the country with a multiracial constitution instead of reciprocating the honourable generosity of the high chiefs in giving Fiji to the Queen in 1874. At the April 1977 election, Sakeasi Butadroka’s Fijian Nationalist Party split the Fijian vote, with the unexpected and unwanted consequence that 
the National Federation Party narrowly won the election, with 26 seats to the Alliance's 24 . Cold feet, indecision among party members over who should be prime minister, and the reaction of indigenous Governor General Ratu Sir George Cakobau ensured that the largely Indian-backed party was never to govern. Ratu Mara was returned at the head of a minority government. When minority government proved unworkable, the Governor General called for fresh elections, which were held in September 1977. The Alliance won.

This was an experience repeated, without the constitutional niceties, a decade later, when Lieutenant Colonel Sitiveni Rabuka seized control in a bloodless coup to depose the government of Dr Timoci Bavadra. In power for only a month, Bavadra's Labour government had won the 1987 election in coalition with the National Federation Party, inauspiciously bringing together the two major Indian parties and, probably forever, undermining Labour's claims that it could or would supersede the politics of race.

The 1987 coup shattered the country's second vision of a multiracial future, centred on the coming together of Fijians and Indians in the towns and in the cane belts of western Viti Levu and the 'friendly north', the Macuata region around Labasa on Vanua Levu. The 'facade of democracy', as Asesela Ravuvu put it, had been cracked. ${ }^{6}$ The idea that Fijians would ever accept an Indian prime minister, or a government in which the largely Indian-backed parties had a majority, had been exposed as an illusion, or so it was said around the yaqona bowls. What would have happened if the Indian population had kept climbing? Would the loss of illusions have entailed dictatorship, spearheaded by the overwhelmingly indigenous Republic of Fiji Military Forces? That we shall never know, for, by the mid-1980s, the Fiji Indians started leaving in large numbers to live in New Zealand, Australia, the USA or Canada, where their race counts for little and where talent is amply rewarded.

Mahendra Chaudhry's rise to power in 1999 was on the back of a third vision of a multiracial future, but it was not his own. The 1997 constitution had been principally the dream of Fijian coup leader Sitiveni Rabuka and opposition leader Jai Ram Reddy, although Labour's Krishna Datt played an insufficiently acknowledged role. In Jai Ram Reddy's speeches, the new vision was quite explicitly counterpoised to the class-based party-building approach espoused by the Labour Party: 
You can have multiracialism in two ways. You can ... have multiracial parties ... That kind of multiracialism is, maybe, a bit premature for Fiji, perhaps we are not ready for it ... The communal pulls are extremely strong ... we are locked into a situation where we will continue to look into the indefinite future in terms of race ... There is another kind of multiracialism ... Let us each be in our separate racial compartment ... Let communal solidarity prevail ... Let everyone be united, but from our respective positions of unity, let us accept that we must co-exist and work together ... It may be ... that that is a more realistic approach. ${ }^{7}$

Communal seats were thus retained in the 1997 constitution. Indeed, there were now 46 of them as opposed to the 27 under the 1970 constitution. ${ }^{8}$

Other tensions emerged between the political leaders' views and those of the Constitutional Review Commission (CRC) entrusted with preparing the proposal for Fiji's fundamental laws. The CRC wanted fewer communal seats, and looked not so much to the emergence of multi-ethnic political parties, but rather to sophisticated electoral mechanisms to deliver inter-ethnic compromise and a multiracial government. The politicians were, perhaps rightly as it turned out, not convinced that this would necessarily happen. They superimposed the power-sharing provisions on top of a basically Westminster-based constitution, in ways that jarred and creaked at times under the heavy weight of controlling government formation. More than once, the courts were to be transformed, effectively, into law-makers. Disquiet about those various provisions was still notable in the aftermath of the 2006 general election, when Mahendra Chaudhry found he could not assume the position of Leader of the Opposition because his party was in government, and when Prime Minister Qarase, as he explains in this volume, found that backbenchers from the now allied Fiji Labour Party could not legally function as a check and balance in the legislature.

During 1997-1999, the Labour leader had been transformed from critic to strong advocate of the 1997 constitution, but he never quite mastered the style of leadership it required. Rising on the crest of a wave of dissatisfaction with the government of Sitiveni Rabuka, his party obtained an absolute majority at the election in 1999, aided in no small way by the new electoral provisions. The overthrow of Chaudhry's government a year later seemed to confirm, yet again, the notion that democracy works only as long as the indigenous Fijians win. But there is room for reasonable doubt. In 1987, the Bavadra government had lasted just a month before it was overthrown. The 1999 People's Coalition 
government faced down the initial challenge within days of the announcement that $\mathrm{Mr}$ Chaudhry was to become the country's first-ever Indian prime minister, and lasted a full year in office. President Ratu Mara came to the Labour government's assistance in the early days, and calmed the disquiet of the leaders of the small and fractious Fijian parties that had so helped Labour to win.

Labour had an unshakeable mandate, Chaudhry would continually say during that turbulent year, but Fijian allies were indispensable if one recognized the security threat. When the dam finally burst on 19 May 2000, it was called a 'civilian coup'. But civilian coups are never quite possible in a country with as large an army as Fiji's. A small squad of crack soldiers from the élite Meridian Squadron supported the coup, and its ultimate fate rested critically on provoking wider military support. Given the role the military played in ultimately defeating George Speight, perhaps a more solid alliance between the commander of the military forces and the government might have seen off the threat in May 2000, or put Labour back in office in its aftermath. The refusal of Ratu Epeli Ganilau, himself a former military commander, to take the position of Home Affairs Minister in the Chaudhry government, weakened the link with the military and left that crucial ministry unable to respond effectively to the gathering storm clouds of Fijian discontent. As the 2006 campaign commenced, military commander Voreqe Bainimarama gave a lot more than just the impression that he would back the re-election of a Labour government, and made it clear he would defend such a government to the hilt. Back in 2000, the military's position was less clear.

The multiparty cabinet forged in 2006 differed in three critical respects from that formed in 1999, all of which undoubtedly improved the former's prospects (even if the arrangement, despite those advantages, was still to prove highly precarious). First, it was the Fijian party that had the premiership and that was in the ascendancy. Given the Fijian majority in the population, a multi-ethnic government led by a mainstream indigenous party was always more likely to succeed. Second, the other participating party, the Labour Party, was the undisputed majority party of the Indian community. By contrast, the 1999 elections had not met Jai Ram Reddy's expectation of two triumphant robust communal parties, each retaining solidarity in their own racial compartments. Labour had obtained strong Indian support, but the Fijian vote had splintered. Rabuka's Soqosoqo ni Vakavulewa ni Taukei (SVT) had obtained the largest 
share of the Fijian vote (38 per cent), but the new preferential voting system had worked against it. The SVT won only eight seats, well below the 18 it might have had if the election had been conducted under the former first-past-the-post system. With those eight seats, it only just qualified for inclusion in cabinet in accordance with the multiparty cabinet rules. But this inclusion was not to happen. The former governing party was deeply disappointed by its electoral defeat, and put up conditions for participating in the Labour cabinet. Chaudhry did not negotiate, and the courts later found the prime minister's exclusion of the SVT from government to be in accordance with the constitution. Looking back later, other judges - as they struggled with the complexities of the multiparty cabinet provisions after the 2001 elections - were less certain. ${ }^{9}$

The third critical difference distinguishing the 2006 post-election setting from that of 1999 affected the fundamental calculus of Fiji's electoral politics. Changing proportions of the major ethnic groups in the population had secured the position of the indigenous Fijians, and perhaps moved Fiji away from those troubled years when minor variations in the turnout or vote-splintering could make a major difference to electoral outcomes. In a system in which most Fijians vote for one party and most Fiji Indians for another, demographic shifts in ethnic populations assume great importance, as a number of contributors to this volume point out. And as more Fiji Indians than Fijians are emigrating, the arithmetic of demography is working relentlessly against the Fiji Labour Party, especially in the open constituencies where everyone can vote together, and where outcomes are often determined by which group has the slight majority. The ironic effect may be to enhance inter-ethnic cooperation in government as the Fiji Indians, losing numbers all the time, recognize that power-sharing offers the best chance of a place at the table. By a demographic route, has Fiji reached the destination envisaged by the architects of the 1997 constitution? More doubtful is whether or not communal solidarity can and will prevail, in the way the constitution-framers envisaged, as the forces that bound both communities into a bipolar two-party system dissipate. If communal solidarity fades and the people of Fiji begin to divide along different lines, the mechanics and campaign strategies at future elections will be very different from those of 1999, 2001 and 2006. That will complicate matters, and may, by that odd, long and painful route, make the victors in future elections those who are less steeped in the communal politics of the past. 


\section{Notes}

1 The Roko Tui were chiefs installed as salaried governors of the provinces. Within the provinces, local government was organized through the tikinas, districts made up of several connected social groups (the vanua). Those who took charge of these groups, often also chiefs, were called 'Buli', and were responsible for levying taxes, maintaining the order of villages, implementing provincial council resolutions and ensuring provision of services (lala) for higher chiefs (Macnaught, J. 1982. The Fijian Colonial Experience: A Study of the Neotraditional Order under British Colonial Rule Prior to World War II, ANU, Canberra, 1982, pp.4-5.)

2 Colonial controls over the Fijian administration were strengthened; restrictions on Fijians entering contracts were eased; and the former taxation-in-kind scheme was replaced by a more flexible system allowing cash payments. Crucially, however, full-scale land privatization was halted by Sir Arthur Gordon in the British House of Lords. Had the Edwardian boom and the accompanying heyday for Pacific plantations continued, pressures for opening up Fijian lands might have been much greater.

3 One of the key issues in the election was the SDL/FLP conflict over whether the Native Land Trust Act or the Agricultural Landlord and Tenants Act was the appropriate legislation covering land leasing.

4 All voters had four votes - one in their own communal constituency (either Fijian, Indian or General) and another three in 'cross-voting' or 'national' constituencies, where eligible citizens of all races voted together but for candidates whose ethnicity was specified as Fijian, Indian or General.

5 Norton, R. 2004. 'Seldom a transition with such aplomb: from confrontation to conciliation on Fiji's path to independence', Journal of Pacific History, 39(2): 163-84.

6 Ravuvu, A. 1991. The Facade of Democracy: Fijian Struggles for Political Control, 1830-1987, Institute of Pacific Studies, USP, Suva. See also, Scarr, D. 1988. Fiji: The Politics of Illusion, New South Wales University Press, Sydney.

7 Hansard (Suva: Parliamentary Debates, House of Representatives, Fiji, 24 July 1992), pp.730 731.

8 Parliaments under the 1970 constitution had 52 seats, whereas under the 1997 constitution they had 71 seats, but the percentage of communal seats under the 1997 constitution was larger (65 per cent compared with 52 per cent).

9 The Supreme Court later reviewed these issues emphasizing greater scope for different interpretations depending on circumstances: ' ... even an invitation or acceptance expressed to be subject to conditions may not represent a failure to invite or an act of declining. Allowance must be made for the possibility that, in political negotiations, the forceful assertion of a requirement may not represent a final position. This Court construed the letter of purported acceptance under consideration in the 1999 Supreme Court opinion as a final non-negotiable position. That was a finding of fact 'in the circumstances' of the case. In other circumstances, even a similarly expressed "acceptance", or "invitation", may lead to a different conclusion. We should add that rigid stances are not readily reconciled with the Compact and the spirit of the Constitution as a whole'. (Qarase v. Chaudhry, Supreme Court, 18 July 2003, paragraph 134 , p.46). We are indebted to Jone Dakuvula for highlighting the significance of this later comment. 